Nordisk Tidsskrift for Kriminalvidenskab, 1991.

\title{
SELVMORD I DANSKE FÆÆNGSLER OG ARRESTHUSE
}

En undersøgelse som dækker 10-året 1.4.1977-31.3.1987.

W. FREES CHRISTIANSEN

Indsatte i åbne og lukkede fængsler, i arresthuse og Københavns fængsler er berøvede deres personlige frihed i kortere eller længere tid. De kommer ofte fra en tilværelse med store personlige og sociale problemer og en hverdag, som er usikker og indviklet. Mange er belastede af tidligere psykiske lidelser eller lever med et stofog/eller alkoholmisbrug. På den baggrund er det vel ikke sært, at nogle bukker under og tager deres eget liv.

Det har været hensigten med denne undersøgelse at få et indtryk af klientellet og dets selvmordshyppighed for om muligt at begrænse antallet af selvmord. En tidligere dansk undersøgelse af denne art er vistnok ikke udført.

\section{Materiale og metode}

Med Justitsministeriets tilladelse blev undersøgelsen iværksat. Lov om ligsyn m.v. af 26. maj 1976, som trådte i kraft 1. april 1977, var gyldig i hele undersøgelsesperioden. Lovens $\S 3$, hvorefter de betragtede dødsfald indberettedes til politiet, medførte retslægeligt ligsyn efter $\S 4$ og oftest obduktion. Det har således været muligt ved henvendelse til landets politikredse at indsamle politirapport, dødsattest og obduktionserklæring på samtlige selvmord, ligesom afdødes tidligere og aktuelle kriminalitet har kunnet oplyses. Ved siden af politiets registrering af disse dødsfald, havde fængslerne og arresthusene pligt til at indberette selvmordene til Direktoratet for Kriminalforsorgen, hvorfra en liste over dødsfaldene blev indhentet og sammenlignet med politiets registreringer. Med denne dobbeltkontrol menes samtlige selvmord i perioden at være kendt. Detentionsanbragte selvmordere er ikke medtaget i denne del af undersøgelsen.

Materialet er suppleret med oplysninger om den enkelte fra Kriminalforsorgen i frihed og af inspektionsjournaler fra fængslerne. Lægejournaler fra arresthuse og fængsler er gennemgået. Igennem Institut for Demografisk Psykiatri er oplysninger fra indlæggelser på psykiatriske hospitaler og afdelinger bragt til veje.

Fra midten af 1990 er bearbejdning af materialet påbegyndt. De mange oplysninger om hver enkelt er blevet sammenskrevet i form af sygehistorier, der beskriver den enkeltes livsforløb så fyldigt som muligt. Anamneserne indeholder en kort omtale af tidligere og aktuel kriminalitet. Skemaer, tabeller og andre oversigter over materialet er derefter udarbejdet. 


\section{Resultater}

65 formodede selvmordsberetninger blev indsamlet. En kritisk gennemgang af disse har reduceret antallet med 4, således at 61 indgår i det materiale, der gøres rede for. Forudsætningen for dette fravalg har været den definition af selvmord, som er lagt til grund for undersøgelsen. Efter WHO's foreslåede definition er et selvmord »en handling med dødelig udgang, som afdøde, med viden eller forventning om et dødeligt udfald, selv havde foranstaltet og gennemført med det formål at fremkalde de af den afdøde ønskede forandringer.« (1)

Det skal kort omtales, at dødsmåden for de 4, der ikke er medtaget, sandsynligvis var ulykkestilfælde for de 3's vedkommende og ikke fuldt oplyst i eet tilfælde. Dødsårsagen var med temmelig stor sikkerhed forgiftning $\mathrm{i}$ alle 4 tilfælde. Interesserede kan få nærmere oplysninger om disse 4 dødsfald ved henvendelse til forfatteren. De 61 selvmordere, som betragtes, omfatter 4 kvinder og 57 mænd.

\section{Selvmordshyppigheden i perioden}

Selvmordshyppigheden i en befolkning beregnes ofte som en rate, d.v.s. antal af selvmord pr. 100.000 indbyggere (i en standardiseret befolkning). Denne rate var i gennemsnit for 10-året 1977 til 1986 for hele befolkningen 27, højest i 1980 med 32, lavest i 1978 med 23. Der var i befolkningen i samme periode en markant kønsforskel, idet kønsraten var 35 for mænd og 20 for kvinder, altså 1,7 til 1,8 gange højere for mænd. Denne forskel i kønsraten gjorde sig ensartet gældende i hele perioden, om end ikke lige stærkt $i$ alle aldersklasser. Forskellen var mindst $i$ aldersgruppen 5054 år, hvor raten var 1,4 større for mænd end kvinder, højest i aldersgruppen over 85 år, hvor mænd havde en godt 4 gange højere selvmordsrate. Raterne giver et billede af befolkningens selvmordsrisiko (2), og repræsenterer i øvrigt de bedst mulige, som kendes. Dødsmåden har ikke altid været kendt, og bl.a. af den grund er dødsårsagsstatistikkens tal ikke helt nøjagtige. Det anvendte, statistiske materiale baserer sig på oplysninger om personer, d.v.s. dødsattester for så vidt angår selvmordene, registeroplysninger i Danmarks Statistik, hvad angår befolkningsstatistikken.

Selvmord pr. 100.000 indbyggere i aldersgrupperne. Gennemsnitsrater for 1977-86

\section{Tabel 1}

\begin{tabular}{lrrrrrrrrrrr} 
Mænd & 9 & 23 & 33 & 40 & 46 & 53 & 59 & 59 & 61 & 60 & 54 \\
Kvinder & 4 & 9 & 15 & 17 & 23 & 31 & 35 & 41 & 40 & 40 & 37 \\
Raten for begge & køn 27 & \multicolumn{3}{c}{ Raten for moend 35} & \multicolumn{5}{c}{ Raten for kvinder 20}
\end{tabular}

Kriminalforsorgens statistikker oplyser om indsættelser i arresthuse og fængsler, men ikke om personer. Samme person kan være indsat adskillige gange i løbet af et år, og inden for dette i øvrigt i flere arresthuse eller evt. fængsler. Indsættelsestiden 
for den enkelte varierer. Hvis samtlige indsættelser i landets arresthuse og fængsler i løbet af eet år kendes, og indsættelsesvarigheden for den enkelte indsatte ligeledes, kunne en selvmordsrate beregnes med god nøjagtighed. Dette er desværre en fuldstændig uoverkommelig opgave. Ikke engang et omtrentligt tal kan beregnes, idet f.eks. antallet af genindsættelser i løbet af eet år varierer meget fra arresthus til arresthus (3) og i øvrigt normalt ikke kendes. Genindsættelser af samme person i landets fængsler i løbet af et år sker temmelig sjældent (3). Vil man udregne en rate, må en sådan derfor beregnes ud fra antallet af indsættelser i løbet af et år. Indsættelserne repræsenterer færre personer, og selvmordsraten beregnet ud fra indsættelserne er derfor lavere end den ville være, hvis man kendte persontallet i perioden, standardiseret på bedst mulige måde. Et par eksempler kan anskueliggøre dette. Hvis de ca. 34.000 indsatte mænd repræsenterer 17.000 (standardiserede) personer bliver selvmordsraten for mænd 34, altså næsten svarende til kønsraten i befolkningen for mænd. For kvinder kan tilsvarende beregnes, at raten bliver ca. 40, altså væsentligt højere end for kvinderne i befolkningen. Et groft indtryk af den betragtede populations selvmordsrate får man dog, og denne kan nok bruges, hvis man ønsker at følge udviklingen fremover.

I skematisk form (tabel II, III og IV) bringes oplysninger om de skete selvmord i Københavns fængsler og arresthuse samt i Kriminalforsorgens anstalter.

\section{Tabel II}

De indsattes aldersfordeling fordelt på kønnene. Gennemsnit for 1977-86

Arresthuse/Københavns Fængsler

$\begin{array}{lrrrrrrl}\text { Alder } & 15-17 & 18-20 & 21-24 & 25-39 & 40-59 & 60-\text { og derover } & \\ \text { Mænd } & 1286 & 4172 & 5750 & 11358 & 2852 & 211 & \text { i alt indsæt. 25629 } \\ \text { Kvinder } & 86 & 237 & 376 & 711 & 168 & 12 & \text { i alt indsæt. } 1590\end{array}$

I alt 27219 indsættelser om året i gennemsnit, heraf $94 \%$ mænd og $6 \%$ kvinder.

De indsatte selvmorderes aldersfordeling 1.4.77-31.3.87 kønsfordelt.

Selvmordsraten anført i parentes. Arresthuse og Københavns Fængsler.

$\begin{array}{lcccccccc}\text { Mænd } & 0(0) & 3(7) & 10(17) & 23(20) & 12(42) & 1(47) & \text { i alt } & 49 \text { mænd } \\ \text { Kvinder } & - & - & 1(27) & 3(42) & - & - & \text { i alt } & 4 \text { kvinder }\end{array}$

Selvmordsrate for mænd + kvinder $(5,3 \times 100000)$ : $\quad 27219$ d.v.s. 19

Selvmordsrate for mænd $\quad(4,9 \times 100000): \quad 25629$ d.v.s. 19

Selvmordsrate for kvinder $\quad(0,4 \times 100000)$ : $\quad 1590$ d.v.s. 25 
Tabel III

Indsatte i Kriminalforsorgens Anstalter. Gennemsnit for 1977-1986.

Aldersfordelingen kendes ikke.

Mænd 8464 indsatte

i alt 8808 indsættelser, heraf $96 \%$ mænd, $4 \%$ kvinder.

Kvinder

344 indsatte

De indsatte selvmorderes aldersfordeling 1.4.1977-31.3.1987.

Kriminalforsorgens Anstalter.

Alder $\quad 15-17 \quad 18-20 \quad 21-24 \quad 25-39 \quad 40-59 \quad 60$ år og derover

$\begin{array}{llllllll}\text { Mænd } & 0 & 1 & 1 & 3 & 3 & 0 & \mathrm{i} \text { alt } 8 \text { mænd }\end{array}$

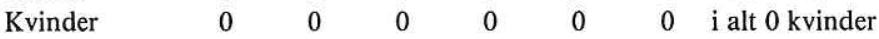

Selvmordsrate mænd + kvinder $(0,8 \times 100000)$ : 8808 d.v.s. 9

Selvmordsrate for mænd 9

Selvmordsrate for kvinder 0

Tabel IV

Indsat i Københavns Fængsler og arresthuse samt i Kriminalforsorgens Anstalter i gennemsnit i perioden 1977-1986 fordelt på køn:

Kvinder $\quad 1934$

i alt 36027 indsættelser i gennemsnit om året.

Mænd 34093

Kvindernes antal 5\%, mændenes $95 \%$.

I alt 61 selvmord fra 1.4.1977-31.3.1987, heraf 4 kvinder og 57 mænd.

Selvmordsraten for begge køn i alle institutioner 17

Selvmordsraten for kvinder i alle institutioner $\quad 21$

Selvmordsraten for mænd i alle institutioner $\quad 17$

Betragter man de generelle selvmordsrater fra arresthuse/Københavns Fængsler $19 \mathrm{i}$ alt, for mænd $19 \mathrm{og}$ for kvinder 25 - får man måske indtryk af, at selvmordshyppigheden $\mathrm{i}$ disse institutioner er lavere end $\mathrm{i}$ befolkningen som helhed. Tallet skal imidlertid korrigeres med en ukendt faktor, som tidligere anført, for at kunne sammenlignes med befolkningens rater. Antallet af genindsættelser skønnes at udgøre ca. $25 \%$ af alle indsættelser (3), og en del af indsættelserne er ret kortvarige, således at aldersfordelingen påvirkes stærkt heraf. Sikre konklusioner kan derfor ikke drages, ud fra disse sammenligninger. Den påstand fremsættes dog, at selvmordshyppigheden for moend noppe er højere end i befolkningen som helhed.

Hvad kvinderne angår, ser man ret umiddelbart, at raten er højere end blandt kvinderne $\mathrm{i}$ befolkningen, især hvis man vil arbejde med en korrigerende faktor på f.eks. 1,5 til 2. Raten i aldersgruppen 21-24 er 27 og i aldersgruppen 25-39 42, men de små tal, der ligger til grund, muliggør, at tilfældige variationer får en meget stor 
vægt. Det kvindelige klientel udgør ca. 6\% af de indsatte, men vægter med 7,5\% i selvmordsmaterialet. Det er et åbent spørgsmål, om kvinder har en højere selvmordsfrekvens under indsættelse i arresthuse/Københavns Fængsler end forventet, når selvmordsrater i befolkningen lægges til grund. Den hypotese fremsættes hermed, at indscettelse af kvinder $\mathrm{i}$ arresthuse/Københavns Fængsler er en reel selvmordsdeterminant.

Tabel III giver oplysning om indsatte i Kriminalforsorgens anstalter (åbne og lukkede) for perioden 1977-1986. For indsatte i disse institutioner gælder, at genindsættelseshyppigheden er lav og næppe mere end $1 \%$ (3). De indsatte sidder gennemgående inde ret lang tid, hvorfor aldersfordelingen ikke påvirker raterne så meget. De lave selvmordsrater er derfor nok til en vis grad sammenlignelige med befolkningens, og dette taler absolut for, at selvmordshyppigheden for indsatte $i$ Kriminalforsorgens anstalter er lavere end i befolkningen.

Tabel IV viser, at selvmordsraten for mænd ligger omkring 17. Det indtryk bliver stående, at mænds selvmordsrate er som befolkningens i almindelighed, såfremt en korrigerende faktor på 2 bliver anvendt. Det tidligere anførte om kvinderne ændres ikke af tabellens rate på 21 .

Det havde været interessant at se, hvor stor en del af samtlige dødsfald (ved alle dødsmåder) $\mathrm{i}$ arresthuse/Københavns Fængsler og Kriminalforsorgens anstalter selvmordene udgjorde i perioden. Der findes imidlertid ikke tal for disse dødsfald (4), så denne opgave har ikke kunnet løses.

Mens mange statistikker om selvmord sandsynligvis underrapporterer selvmordenes faktiske forekomst (1), der delvis skjuler sig under ulykkestilfælde og naturlig død, så er den her fremlagte opgørelse nok ret nær ved at have registreret de fleste selvmord. Enkelte af selvmordene kan have været ulykkestilfælde, men i reglen kendes dødsmåden med stor sikkerhed. Hensigten - at ville begå selvmord - er i mange tilfælde klart belyst i afskedsbreve og med udsagn herom. Selvmordsforsøg er ofte gjort tidligere. På den anden side kendes de øvrige dødsfald i de betragtede institutioner desværre ikke, og det er derfor umuligt at vide, om der blandt de naturlige dødsfald kunne skjule sig et selvmord, f.eks. ved medicinforgiftning, eller om enkelte ulykkestilfælde i virkeligheden var selvmord. Den retslægelige behandling af alle disse dødsfald gør det dog mindre sandsynligt, at en evt. fejlregistrering af dødsmåden er sket særlig ofte.

Oplysninger om selvmordsraten i udenlandske fængsler m.v. er vanskelige at bedømme. Det er ikke altid let at se, om der tales om antallet af selvmord pr. 100.000 personer (idet beregningen ofte sker ud fra prisoners, Inhaftierte), eller pr. 100.000 indsatte (inmates). Undertiden beregnes raten ud fra middelbelægningen. I USA benyttes sommetider en rate pr. 100.000 prisoner years (5). I en artikel fra 1983 (6) anføres raten at være $57 \mathrm{pr} .100 .000$ inmates, og det siges, at denne rate er mindst 3 
gange så høj som i befolkningen uden for »penal institutions«. Den anførte rate harmonerer ikke helt med en anden angivelse fra 1987 (7), hvorefter raten fra 1980 til 1983 var 23,5 pr. 100.000 prisoners pr. år. I perioden 1945 til 1974 var den i Bayern (8) 29,3 pr. 100.000 Inhaftierte, og kun ubetydeligt højere end selvmordsraten for mandlige civilpersoner i de samme år $(25,9)$. I England var raten i 1958 til $197114 \mathrm{pr}$. 100.000 indsættelser (receptions) (9). I skotske fængsler var den mellem 1970 og 198251,8 pr. 100.000 fanger, beregnet ud fra middelbelægningen (10). Forfatteren gør opmærksom på vanskelighederne ved rateberegningen i »a changing population«. I Holland fandt man for perioden 1973 til 1984, når antallet af indsatte pr. dag i 1980 blev lagt til grund, en selvmordsrate mellem 61,6 og 207,2 pr. 100.000. Sammenlignet med suicidalraten for 20-49 årige mænd i samfundet som helhed påvistes herved groft taget en 10 gange højere selvmordsrate i fængsler og arresthuse (11).

Selvmordsraten veksler i øvrigt fra institution til institution. Dette er i sig selv næppe overraskende. Blandt danske åbne og lukkede fængsler fandt 3 selvmord sted i anstalten ved Herstedvester med 1647 indsættelser fra 1977-86, d.v.s. 182 selvmord pr. 100.000 indsættelser. Denne institutions klientel omfatter mange psykisk syge, således også psykisk syge overført fra nogle arrester eller andre fængsler. På psykiatriske hospitaler forekommer også en del selvmord, og en californisk undersøgelse (12) har vist, at i Californiens eneste sygehus med maksimale sikkerhedsforanstaltninger, var selvmordsraten den samme som eller endda mindre end på mange andre sygehuse for psykisk syge.

\section{Kriminaliteten}

De suicideredes kriminalitet er forsøgt vurderet med henblik på dens mulige betydning for selvmordshandlingen. De 61 dødsfald blev derfor rubriceret efter den seneste alvorlige eller helt overvejende kriminalitet før den sidste indsættelse. De tilvejebragte oplysninger er givet herunder i skematisk form.

Skemaet omfatter 8 grupper. I hver gruppe anføres to tal. Det første er dømte, det andet ikke dømte selvmordere (sigtede og/eller tiltalte). Skemaet omfatter 20 dømte og 41 ikke dømte personer.

Alle grupper vedrører overtrædelser af Borgerlig Straffelov. Det har nemlig vist sig, at 60 selvmordere havde begået straffelovsovertrædelser, der enten var så alvorlige, at de umiddelbart repræsenterede de alvorligste, strafbare forhold, eller - hvor mindre alvorlige overtrædelser forelå - var den helt overvejende kriminalitet, som pågældende blev dømt, tiltalt eller sigtet for. Een selvmorder afsonede hæftestraf for et ukendt strafbart forhold. 
Kriminaliteten fordelt på 8 grupper (personer)

Gruppe 1. Berigelsesforbrydelser og andre

$$
\text { Dømte Ikke-dømte I alt }
$$

formuekrænkelser (Strfl. §§ 276-

305)

11 pers.

13 pers.

24 pers.

Gruppe 2. Forbrydelser i familieforhold.

Forbrydelser mod kønssædelig-

heden (Strfl. §§ 208-236)

Gruppe 3. Forbrydelser mod liv og legeme (drab/drabsforsøg) (Strfl. $\S$ 237-241)

2

(vold m.v.) (Strfl. §§ 244-249)

Gruppe 5. Forbrydelser mod den personlige frihed (Strfl. §§ 260-262)

Gruppe 6. Almenfarlige forbrydelser (Strfl.

Gruppe 6. Almenfarlige forbrydelser (Strfl.
$\S \S 191,191 \mathrm{a})$ og lov om euforiserende stoffer

Gruppe 7. Almenfarlige forbrydelser (Strfl. $\S \S 180$ og 181)

Gruppe 8. Forbrydelser mod offentlig myndighed (Strfl. § 119)

Lovovertrædelser uoplyst

Gruppe 4. Forbrydelser mod liv og legeme
1

$\begin{array}{lll}4 & 7 & 11\end{array}$

$\begin{array}{lll}0 & 1 & 1\end{array}$

$\begin{array}{lll}0 & 1 & 1\end{array}$

1 hæftestr.

20

41

61

De paragraffer, efter hvilke de dømte sad inde på dødstidspunktet, foreligger naturligvis oplyst. Derimod er de paragraffer, som sigtede og - sjældent - tiltalte var indsat efter, ikke altid præcist oplyst. Sigtelsernes indhold er dog altid kendt og blevet brugt så godt som muligt $i$ den her foreliggende sammenhæng. I en del tilfælde har kriminaliteten skullet henføres til flere grupper, således at 60 selvmordere, hvad angår kriminaliteten, fordeler sig på 88 registreringer. Den kriminalitet, hvis strafferamme betingede den hårdeste straf, er i skemaet betragtet som den alvorligste. En hæftestraffets kriminalitet er desværre uoplyst.

Berigelsesforbrydelser var begået af $\mathrm{i}$ alt 34 personer. 24 af disse havde denne form for kriminalitet som den væsentligste kriminalitet. 10 personer havde begået andre forbrydelser, som var alvorligere, men altså også berigelsesforbrydelser. 7 af berigelsesforbrydelserne var røverier. 3 var dømt, 4 tiltalt herfor. Over halvdelen af de suiciderede gjorde sig således skyldige i berigelsesforbrydelser.

Samler man den kriminalitet i een gruppe, der var karakteriseret ved en mere eller mindre voldelig adfaerd, mens lovovertrædelserne blev begået, omfatter en sådan 
gruppe 13 personer, som begik drab eller drabsforsøg, 5 personer som havde gjort sig skyldige i grove former for vold, 2 som forbrød sig mod den personlige frihed, 1 person som begik voldtægt, 1 som havde forsøgt dette, 1 som var sigtet for forsætlig brandstiftelse og 1 som var sigtet for vold mod politiet, i alt 24 personer. Blandt disse 24 var 2 røvere. Tilføjer man de 5 øvrige røvere, omfatter gruppen i alt 29 personer, altså næsten halvdelen af de suiciderede.

Skemaets gruppe 6 omfatter 11 personer. Denne gruppe er i alt væsentligt narkokurerer, narkohandlende og narkosmuglere. Den almindelige narkoman, som begik indbrud, tyverier og lign. for at finansiere sit stofmisbrug, er normalt at finde under berigelsesforbryderne. Gruppe 6 udgjorde knapt $1 / 5$ af de 61 selvmordere.

Een person (en blotter) er anført i gruppe 2, men falder ikke ind under nogen af de tre store grupper, som netop er afgrænset og i det efterfølgende vil blive diskuteret.

Direktoratet for Kriminalforsorgen (4) har ud fra dets register over anmeldte til afsoning for året 1990 oplyst, at ca. $47 \%$ anmeldelser vedrørte straffelovsovertrædelser af anden art end voldtægt, drab, røveri, vold og narkoforbrydelser. Følgende forbrydelser: voldtægt, drab, røveri og vold udgjorde ca. $26 \%$ af anmeldelserne. Narkokriminalitet og overtrædelse af lov om euforiserende stoffer udgjorde knapt $8 \%$, og overtrædelse af våbenlov, færdselslov, særlove i øvrigt og uoplyst lovgivning ca. $19 \%$ af samtlige anmeldelser.

Hvis dette billede stort set også dækker forholdene i årene 1977-1987 er selvmordsundersøgelsens 19 ikke grove berigelsesforbrydere næppe en forventet andel af undersøgelsens totalantal, idet de kun omfatter ca. $31 \%$ af de 61 personer. Omvendt var den grovere kriminalitets 29 repræsentanter (ca. 48\%) en væsentlig større andel end forventet, og de 11 narkokriminelle viser ligeledes, at denne type kriminalitet var meget stærkt repræsenteret blandt selvmorderne. Sammenligning med de personer, som faktisk indsættes i fængsler og arresthuse, og som i sig selv repræsenterer en udvalgt del af befolkningen, viser da, at blandt indsatte i de betragtede institutioner under Kriminalforsorgen er to grupper scerligt selvmordstruede: Sådanne, som begik alvorlig kriminalitet og narkohandlere, -kurerer og lign.

For at besvare det spørgsmål, om kriminalitet - $i$ al fald som et medvirkende forhold - har betydning for en selvmordsbeslutning, er det imidlertid af betydning at kende befolkningens kriminalitet lidt nøjere for at se, på hvilken måde de indsatte suicideredes kriminalitet adskiller sig fra befolkningens. Et fingerpeg herom er naturligvis givet i det foregående.

Sager med økonomisk værdi, afgjort i første instans, samt overtrædelser af færdselsloven synes at være befolkningens hyppigste forseelser. I den her betragtede sammenhæng er de uden betydning.

Herefter følger ejendomsforbrydelser (13). Statistikkerne over tiltalefrafald, bødeafgørelser og domfældelser efter Borgerlig Straffelov viser, at i 1977-1986 vedrørte $72-75 \%$ af alle domfældelser til højere straf end bøde for overtrædelse af Borger- 
lig Straffelov sådanne forbrydelser. Som nævnt havde især 24, men i alt 34 af selvmorderne begået denne form for kriminalitet, og dette efterlader det indtryk, at denne kriminalitet, som altså er ret almindelig i befolkningen, ikke specielt karakteriserer den betragtede gruppe selvmordere. Dette indtryk befæstes især, hvis man fra de 34 personer trækker de 15 - omfattende 7 røvere og 8 med anden, alvorligere kriminalitet - hvorved tallet på de mere »fredelige« berigelsesforbrydere bliver 19. En gennemgang af sagsmaterialet for de 19 selvmordere, der begik berigelsesforbrydelser, giver da heller ikke sikre eksempler på, at berigelseskriminaliteten har haft nogen betydning for selvmordsbeslutningen.

I et tilfælde af bankrøveri var der dog ikke tvivl om, at kriminaliteten i sig selv spillede en rolle for selvmordsbeslutningen. Dette eksempel anføres på denne plads, fordi det binder visse ejendomsforbrydere sammen med gruppen af personer, der begik alvorligere kriminalitet.

En 49-årig person var tidligere ustraffet og sad i en god stilling på tidspunktet for røveriet, som blev gennemført med en legetøjspistol og en sten, der fingerede en granat. Kort før sin død havde han søgt læge for arbejdsbetinget stress. Efter en dårlig nats søvn, bekymret over sin noget yngre hustrus helbredstilstand og besværet af trafikproblemer og dårligt vejr på vej til sit arbejde »slog nerverne klik«, og røveriet blev spontant besluttet og dilettantisk gennemført. Blev hurtigt anholdt.

Begik selvmord ved hængning ca. 1 døgn efter anholdelsen. I et afskedsbrev fortrød han klart sin røveriske handling. Selvdestruktive tanker var formentlig midlertidigt fortrængt, mens røveriet fandt sted. I den efterfølgende fase, hvor skamfølelse og fortrydelse meldte sig, vendte de selvdestruktive tanker tilbage igen.

I befolkningen fandt domfældelser til højere straf end bøde for overtrædelse af Borgerlig Straffelov, når voldtægt, voldsforbrydelser, forsætlig brandstiftelse, røveri og hærværk ses under eet, sted i en procentandel af samtlige domfældelser på ca. 23. I en del tilfælde skete der tiltalefrafald eller en mildere strafudmåling, men selvmordsmaterialets $48 \%$ (af personerne), som må henføres til denne kriminalitet, er absolut en høj andel af selvmordspopulationen.

Det kan nævnes, at blandt straffelovsovertrædelser udgør de samme forbrydelser få procent af anmeldte lovovertrædelser. Indbrud, tyverier, bedragerier og hæleri er her langt de hyppigste, opklarede og anmeldte lovovertrædelser. Dette billede af politiets arbejde kan måske vise, at nok er den alvorlige kriminalitet ikke ualmindelig i befolkningen, men i den samlede kriminalitet spiller andre former kvantitativt en meget større rolle.

Supplerer man de talmæssige betragtninger der er gjort med en gennemgang af den alvorlige kriminalitets journaler, ser man, at kriminaliteten uden tvivl har spillet en betydelig rolle for selvmordsbeslutningen i flere tilfælde. Det gælder især de mange drab og drabsforsøg i ægteskab og samlivsforhold. 
Et par eksempler kan anskueliggøre dette.

En 44-årig mand med en høj uddannelse og i god stilling dræbte sin hustru og sit barn. Han havde på det tidspunkt visse økonomiske spekulationer og betydelige ægteskabelige problemer og søgte psykiaterbistand under hospitalsindlæggelse i sammenhæng hermed. Til sygehusets læger forklarede han om »tvangstanker«, der gik ud på at begå selvmord eller at dræbe hustruen. Begik drabene under orlov fra sygehuset. Var ikke sindssyg under sygehusindlæggelsen. Efter drabene atter i psykiatrisk behandling i fængselsvæsenets regi. Hængte sig 4 uger efter drabene. Besigtigelse på drabsstedet dagen før dødsfaldet »havde påvirket ham alvorligt«. Intet afskedsbrev.

Selvmordstanker og drabstilskyndelse var integrerede dele af denne sjæleligt uligevægtige persons forestillingsverden. Kriminalitetens art og omstændighederne derved var ham utvivlsomt bevidst og stærkt belastende for ham på selvmordstidspunktet.

En 36-årig mand, ustraffet, dygtig til sit arbejde og med en god uddannelse, gjorde et alvorligt drabsforsøg på sin bedste ven. Psykisk og fysisk altid rask. Af karakter stædig, beslutsom og konsekvent. En dygtig planlægger. De sidste ca. 5 måneder af sit liv tegn på seksuelle problemer, var i øvrigt aldrig gået af vejen for »små sidespring «. Lidenskabeligt forelsket i sin vens kone, næppe gengældt. Synes herefter at have planlagt et drab på vennen og - antagelig - senere på sin hustru. Ved den dramatiske anholdelse besluttet på kamp eller selvmord. Dette afværgedes umiddelbart, men selvmordet gennemførtes ved sovemiddelforgiftning i arresten inden for første døgn af indsættelsen.

Kriminaliteten forfejlede sin hensigt, hvorefter selvmordet var en logisk handling.

Det ser ud til, at alvorlig kriminalitet $i$ sig selv kan vaere en selvmordsdeterminant. De 11 selvmord, der forekom blandt personer, sigtet, tiltalt eller dømt for alvorlig narkokriminalitet, udgjorde procentvis $18 \%$ af de 61 selvmord, mens domfældelser til højere straf end bøde for denne type lovovertrædelser i befolkningen kun udgjorde ca. $2 \%$ af samtlige domfældelser, og blandt anmeldte lovovertrædelser kun nogle få promille af samtlige overtrædelser.

Blandt anmeldte overtrædelser af visse sinrlove (13) var andelen af overtrædelser af lov om euforiserende stoffer mellem ca. 15 til $35 \%$ af periodens anmeldelser. Domfældelser efter samme lov udgjorde ca. $2 \%$ af særlovgivningsdomfældelserne, og hovedparten af disse var bødeafgørelser eller betingede straffe.

Det må konstateres, at alvorlig narkokriminalitet var stærkt overrepræsenteret blandt de suiciderede indsatte, og mistanke om denne form for kriminalitet som selvmordsderterminant er til stede. Gennemgår man selvmordernes journaler kan denne opfattelse underbygges i enkelte tilfælde. Dette eksemplificeres herunder.

En 48-årig mand var fra sit 17. til 40, år straffet talrige gange for berigelseskriminalitet (ikke narkotikakriminalitet). Havde i perioder af sit liv et stort alkoholforbrug, men herudover intet kendt misbrug. Mellem sit 40. og 47. år var han ikke fængslet og klarede sig ret godt, bl.a. som gadehandler fra stadeplads. Lod sig som 48-årig friste til forsøg på narkotikasmugling fra et andet europæisk land til Danmark. Fængsledes i det 
pågældende land. Her brød han psykisk sammen, vistnok især under indtryk af trusler fra meddomfældte »udlændinge af mørk lød «. Det lykkedes at få ham i dansk fængsel, hvor tilstanden var svingende, hvad angik hans sindstilstand. 8 dage efter varetægtsfængslingen i Danmark hængte han sig. Af breve til hustruen fremgik, at han fortrød sin kriminalitet.

Sammenhængen mellem kriminaliteten, dens konsekvenser og selvmordet tegner sig ret tydeligt, om end ikke entydigt.

I de fleste tilfælde spillede andre forhold end kriminaliteten en større rolle for disse selvmordere.

Det samlede indtryk af kriminalitetens betydning for selvmordene synes at måtte blive, at visse former for kriminalitet spiller en selvstændig rolle som en af flere faktorer, der indgår i selvmordsbeslutningen. I den forstand er der tale om, at en selvmordsdeterminant har voeret til stede i form af selve kriminaliteten.

I skønlitteraturen indeholder F. M. Dostojefskis store roman »Brødrene Karamassof « et karakteristisk eksempel på en helt klar sammenkobling af forbrydelsen Dmitris formodning om at have dræbt en gammel tjener - og hans selvmordshensigt ved skydning, som særlige omstændigheder bortvejrer.

Undersøgelser i udlandet understøtter til en vis grad, at alvorlig kriminalitet på en eller anden måde spiller en rolle i selvmordsbeslutningen. En hollandsk undersøgelse (11) sammenlignede en gruppe indsatte selvmordere, som var skyldige i mord/drab med en gruppe selvmordere indsat af andre grunde og fandt 6 gange så mange selvmord i den første, som i den anden gruppe. Naturligvis kan andre forhold have spillet en større rolle i selvmordsbeslutningen, f.eks. straffens længde, sindslidelser, afbrydelse af nære kontakter til familie og venner, de særlige fængselsforhold, stofhunger m.m.

Som et andet eksempel, der viser noget lignende, kan nævnes en australsk undersøgelse (14), der i et større fængsel i en periode af 15 år fandt, at $60 \%$ af selvmorderne var tiltalt eller dømt for vold/drab og $20 \%$ for seksualforbrydelser.

Det er dog stadig et diskuteret spørgsmål, om der er en cegte sammenhæng mellem kriminalitet og selvmordsadfærd. I en oversigtsartikel fra 1986 diskuterer J. Modestin (15) denne problemstilling og konkluderer, at der »keine echte innere Bezogenheit besteht, auch wenn beide Verhalten gelegentlich ... gemeinsam auftreten können«. I Danmark har en undersøgelse fra Fyn (refereret i 1) af ganske unges selvmord påvist, at disse unge ofte havde været ude i kriminalitet, men desuden hyppigt var afhængige af alkohol, medicin eller stoffer, altså en anden form for selvdestruktiv adfærd med dybereliggende, psykologiske bevæggrunde som drivkræfter. Denne undersøgelse støtter således til en vis grad den citerede forfatter.

De forskellige meninger, der er omkring dette spørgsmål, bunder nok bl.a. i, at forskellige »årsagsforhold « afdækkes ud fra forskellige indfaldsvinkler. Sociologers, kriminologers og psykiateres, ligesom psykologiske teorier og statistiske undersøgelsesresultater medinddrages. 
At finde en årssagssammenhæng er jo en klassisk måde at forstå et problem på, d.v.s. at »forklare « det (for evt. at bemestre det). I nærværende artikel er begrebet selvmordsdeterminant anvendt som een blandt mange forudsætninger for, at beslutningen om selvmordet blev taget og handlingen udført. I den betydning er der en »innere Bezogenheit«.

\section{Tidligere kriminalitet. Tidligere indsattelser}

Det er ikke muligt at vurdere, om tidligere kriminalitet eller tidligere indsættelser i Kriminalforsorgens institutioner i sig selv har spillet en rolle for den afsluttende selvmordshandling. 9 af de 61 havde ikke tidligere begået lovovertrædelser, som fremgik af straffeattest m.v. 46 vides at have modtaget domme i Danmark. 3 var tidligere straffet i udlandet. 2 havde kun afgørelser tilført strafferegistret. For 1 persons vedkommende var disse forhold uoplyste.

41 (danske) vides at have afsonet tidligere domme i forskellige institutioner. Antallet af domsfuldbyrdelser har varieret meget, mellem een og elleve er noteret. To udlændinge havde været i fængsel i udlandet. Een fransk negers forhold er ikke oplyst.

Varigheden, d.v.s. den samlede faktiske opholdstid i arresthuse/fængsler i forbindelse med afsoningerne, varierede for den enkelte mellem 14 dages hæftestraf og knapt 7 års fængselsophold. 19 havde siddet inde mere end 24 måneder, kun 5 mindre end 3 måneder.

Blandt tidligere (danske) indsatte begik 7 selvmord inden for første døgn af den seneste indsættelse $\mathrm{i}$ arrest/fængsel og yderligere 6 inden for de efterfølgende 7 dage. Knapt $1 / 3$ af tidligere indsatte begik således selvmord ret hurtigt efter påny at være indsat. Sammenligner man denne andel med ikke tidligere (danske) indsattes tilsvarende selvmordstidspukter ( 16 personer, hvoraf $3+6$ begik selvmord inden for første uge) finder man ingen sikker forskel mellem de to grupper.

I det efterfølgende drøftes nogle prolemstillinger, der kan have haft betydning for selvmordsbeslutningerne. Der fokuseres på isolationsfængslings og disciplinære foranstaltningers mulige betydning. Den kriminelle status blandt andre indsatte berøres kort.

\section{Isolation}

Efter Retsplejeloven må isolation anvendes, når varetægtsfængslingens øjemed gør isolation påkrævet. Isolation anvendes antagelig kun, når det er absolut nødvendigt. Herudover sker der former for isolation i forbindelse med enrumsanbringelse, strafcelleanbringelse samt anbringelse i sikringscelle/rum.

I den periode, der her betragtes, var antallet af afsluttede enrumsanbringelser efter Rettens bestemmelser herom ca. 1850 om året (16). Disse indsatte hensad $i$ arresthuse/Københavns Fængsler. 
En anden form for enrumsanbringelse sker efter (berettiget) ønske fra indsatte, og/eller efter institutionslederens beslutning herom. $90 \%$ finder sted i åbne/lukkede anstalter, ca. 10\% i arresthuse/Københavns Fængsler. Antallet udgjorde omkring 1000 om året.

Strafcelleanbringelse er et disciplinærmiddel, som hyppigst bliver anvendt $i$ åbne og lukkede anstalter ( $3 / 4$ af anbringelserne), sjældnere i arresthuse/Københavns Fængsler. Ca. 1300 årligt i perioden.

Sikringscelleanbringelse sker hyppigst i Københavns Fængsler/arresthuse (ca. $70 \%$ af anbringelserne), sjældnere i åbne/lukkede anstalter. Formålet er ofte at hindre selvmord eller anden selvbeskadigelse. 400-450 anbringelser fandt sted om året.

Isolationens betydning for en selvmordsbeslutning og dennes virkeliggørelse bør vel beregnes ud fra alle former for isolationsanbringelse. Lægges denne forudsætning til grund, og beregner man tallet for isolationsanbringelser som summen af $1850+1000+1300+425=4575$, udgør dette tal ca. $17 \%$ af de indsættelser - ca. 27000 - der årligt fandt sted i perioden. Anvender man antallet af egentlige isolationsanbringelser - 1850 - bliver procentdelen af de 27000 indsættelser knapt 7.

Ser man nu på dem, der begik selvmord, finder man, at en hovedpart af selvmorderne d.v.s. 48 ikke var i nogen form for isolation på dødstidspunktet. For 2 personer er det uoplyst, om de var isolerede, men de foreliggende oplysninger henfører dem formentlig til de 48 nævnte.

Af de resterende 11 var een i frivillig isolation i lukket fængsel på dødstidspunktet, een i strafcelle i åben/lukket fængsel, een under skærpet tilsyn i sygeafdeling og to i sikringsrum/celle i arresthuse. 6 var varetægtsfængslede $o g$ isolerede på dødstidspunktet. For een af disse 6 bygger henføringen til denne gruppe på oplysninger, der sandsynliggør, at der var tale om egentlig isolationsfængsling.

11 af 61 selvmordere var således i en form for isolation på dødstidspunktet, d.v.s. $18 \%$. 6 var varetægtsfængslede $o g$ isolerede efter Rettens bestemmelser herom på dødstidspunktet, d.v.s. ca. $10 \%$. Denne procentdel synes at være ret høj, og den mulighed, at egentlig varetægtsisolation kan have medvirket ved selvmordsbeslutningen, er måske rigtig.

Det skal dog bemærkes, at de små talværdier, der lægges til grund for ovennævnte skøn om en ret høj selvmordsdødelighed for varetægtsisolerede, i sig selv muliggør procentvis store svingninger. Hvis f.eks. den mindre sikkert isolerede fraregnes, får man procentandele på $16 \mathrm{og} 8$. Det er endvidere påfaldende, at 3 af de 6 var fremmedsprogede udlændinge, for hvem andre omstændigheder uden tvivl spillede en meget større rolle end isolationsfængsling.

De 11 isoleredes anamneser viser, at for de indsatte i frivillig isolation og i sygeafdeling samt de to sikringscelleanbragte har isolationen med sandsynlighed været uden større betydning for selvmordet. 
Den isolerede i strafcelle, en 27-årig mand af grønlandsk herkomst, havde tidligere været fængslet flere gange. 6 dage før selvmordet skrev han i et brev til en veninde, at "han var glad for at være i fængslet« og glædede sig til at få besøg. Opholdet i strafcellen, var følgen af en »springtur«. Under denne sagde han til en socialrådgiver, at han ikke kunne holde ud at være i fængsel, »nu kan det være nok «. Han havde angiveligt tidligere »oplevet naturen intenst - som en grønlænder gør det «. I forbindelse med stedfaderens død nogle år forinden havde han skåret sig i håndleddet »for at opnå forbindelse med afdøde plejefar«. Det skønnes, at isolationen kan have forstærket suicidale tilskyndelser hos ham. Selvmordet fandt sted på sidste dag af strafcelleanbringelsen, som varede 10 dage.

4 af de 6 egentlig isolerede varetægtsfanger var isolerede i forbindelse med narkoforbrydelser. 3 af dem var udlændinge.

En af udlændingene, en 32-årig neger, slugte glasstumper, tobak og en ring straks efter anholdelsen, måske i selvmordshensigt, hvad hustruen mente. Begik selvmord ved hængning efter at han samme dag kort forinden havde fảet isolationsfængslingen forlænget. Udleveringsangst og frygt for langvarig straf kan have spillet en større rolle end isolationsfængslingen. Hustruen havde i øvrigt under hans fængsling ønsket skilsmisse, hvad han vidste.

Blandt de tre danskere var en kvinde, sigtet for narkohandel. Een var impliceret i tyverier og i øvrigt hash- og alkoholmisbruger. Een var sigtet for forsøg på manddrab. Det kan ikke af deres sagsakter ses, om isolationsfængslingen i sig selv har haft betydning for selvmordet. Andre forhold spillede afgjort en større rolle.

De foreliggende oplysninger hverken af- eller bekræfter, at isolationsfængsling, især efter Retsplejelovens bestemmelser herom, i sig selv spillede nogen større rolle for selvmordsbeslutningen. De to sikringscelleanbringelser kunne desværre ikke forhindre selvmord hos mentalt syge indsatte og forfejlede derfor i nogen grad sigtet med anbringelserne.

Isolationsfængsling giver nu og da anledning til indlæg i Ugeskrift for Læger, senest i juni og oktober 1990 (17). Psykiatere har afgrænset de såkaldte isolationssyndromer, og deres eksistens kan således næppe betvivles. Nærværende undersøgelse kan ikke bidrage til belysning af disse syndromer, idet kun een af de 11 isolerede var i psykiatrisk tilsyn/behandling på dødstidspunktet.

Denne, en 37-årig mand, var sigtet for manddrab. Han var tidligere vurderet af psykiatere under indlæggelse og ambulant. Som 29-31-årig var han i langvarig behandling under diagnosen: Psychosis paranoides (psychogenes) d.v.s. en sindssygdom med massive vrangforestillinger. Blev de sidste 28 dage af indsættelsen, der varede $i$ alt 31 dage, behandlet af psykiater, som fandt ham stillestående og deprimeret med udtalte vrangforestillinger. Havde forsøgt selvmord før drabet, og forsøgte det igen efter indsættelsen dagen før den afsluttende hængning. Var på dødstidspunktet på sygeafdeling og under skærpet tilsyn. 


\section{Disciplincere foranstaltninger}

Disciplinære foranstaltninger i øvrigt omkring dødstidspunktet kunne også tænkes at have spillet en rolle ved selvmordsbeslutningen. Ud over de tidligere nævnte to sikringscelleanbringelser og 1 strafcelleanbringelse synes kun een person - og kun i meget begrænset omfang - at have været underkastet sådanne.

Det drejede sig om en mand, som under orlov fra fængsel undveg fra en ledsagende betjent. Han blev hurtigt genindsat i den stedlige arrest. Her udtrykte han selvmordstanker over for påførende. Begik selvmord to dage efter indsættelsen, før han var tilbageført til fængslet. Var ikke isoleret, sad i enecelle på almindelige vilkår.

På det foreliggende grundlag kan der ikke tilføjes noget til de betragtninger, der er gjort omkring isolationens betydning.

\section{Status blandt medfanger}

Det er et nogenlunde velkendt forhold, at indsatte i Kriminalforsorgens forskellige institutioner har en meget uens status blandt medfanger. Det kunne vel tænkes, at f.eks. personer med en lav status var særligt selvmordstruede i fængselsmiljøet. Det var derfor et ønske at vurdere de 61 selvmorderes status, for om muligt at besvare spørgsmålet. Dette har ikke været muligt med blot nogen sikkerhed. Det ser ud til, at 2 havde en høj, 5 en almindelig, gennemsnitlig og 3 en lav status, men for 51 var forholdet helt uoplyst. Hypotesen forbliver således ubesvaret.

Adresse: Embedslæge W. Frees Christiansen

Østergade 1

DK-8000 Århus C

\section{Litteraturoversigt:}

1. Selvmord og selvmordsforsøg. Uni Bille Brahe, Gertrud Krarup. Bent Nielsen. August G. Wang. Hans Reitzels forlag, 1988.

2. Sundhedsstyrelsen. Dødsårsagerne 1977-1986. Vitalstatistik.

3. Svar på henvendelse af 5.11.1990 til landets fængsler og arresthuse.

4. Oplysninger meddelt af Direktoratet for Kriminalforsorgen i brev af 23.1.1991.

5. A study of 128 Deaths in New York City Correctional Facilities (1971-1976). Implications for Prisoner Health Care. Lloyd F. Novick, M.D., M.P.H., and Elaine Remmlinger, M. Ed. Medical Care. September 1978, Vol. XVI, No. 9. Side 749-756.

6. Suicides in Jails and Prisons. John J. Tuskan, Jr., RN, MSN, Michael E. Thase, MD. Journal of Psychosocial Nursing and Mental Health Services. May 1983, Vol. 12, No. 5. Side 29-33.

7. Suicide and Homicide in USA Prisons. David Lester. Richard Stockton State College. Psychological Reports, 1987, 61. Side 126. 
8. Suizide in bayerischen Volzugsanstalten. W. Spann, E. Liebhardt, S. Seifert. Münchener Medizinische Wochenschrift 121 (1979) Nr. 9. Side 315-316.

9. Suicide in Prison. D. O. Topp. British Journal of Psychiatry (1979) 134. Side 24-27.

10. Suicide in Scottish Prisons. S. A. Backett. British Journal of Psychiatry (1987). 151. Side 218-221.

11. Suicidal Behavior in Jails and Prisons in The Netherlands: Incidence, Characteristics, and Prevention. Ad. J. F. M. Kerkhof, PhD and Wim Bernasco, USA, University of Leiden. Suicide and Life-Threatening Behavior, Vol. 20(2), Summer 1990. Side 123-137.

12. Patterns of Suicide among Hospitalized Mentally Disordered Offenders. Robert L. Haynes, Ph. D., Janice K. Marques, Ph. D. Suicide and Life-Threatening Behavior, Vol. 14(2), Summer 1984. Side 113-125.

13. Statistisk Årbog, Danmark. Årgangene 1978-1988.

14. Suicides by Prisoners. The Medical Journal of Australia 1989. 21.8.1989. Vol. 151. Side 188-190.

15. Über die Beziehung zwischen Kriminalität und Suizidalität. J. Modestin. Fortschritte der Neurologische Psychiatrie. 54 (1986). Side 289-296.

16. Kriminalforsorgens årsberetninger. Oplysninger meddelt fra Direktoratet for de betragtede år.

17. Ugeskrift for Læger 152/24. 11.6. 1990. Isolationssyndromer. Finn Jørgensen. Ulvens Ansigt. Haakon Lærum. Side 1755-1757. Ugeskrift for Læger 152/40. 1.10. 1990. Varetægtsfængsling. Rigsadvokat Asbjørn Jensen. Side 2938-2939.

\section{Meddelelse fra redaktionen}

Vor svenske redaktør, justitierådet Bo Svensson, Högsta Domstolen, har ønsket at hellige sig andre gøremål. Bo Svensson har været redaktør siden 1988, og den øvrige redaktion takker ham for et godt samarbejde.

Den svenske kriminalistforening har i stedet udpeget högskoleadjunkt Lena Holmqvist, Uppsala. Vi byder hende velkommen i vor kreds. 